\title{
Serpentinites of the Ural: Mineralogical Features, Petrophysical Properties and Subduction Processes
}

\author{
T. V. Posukhova, L. L. Panasian, I. E. Sas \\ Mineralogical Department, Geological Faculty, Lomonosov Moscow State University, Moscow, Russia \\ Email: tposukhova@mail.ru
}

Received February 3, 2013; revised March 18, 2013; accepted April 15, 2013

Copyright (C) 2013 T. V. Posukhova et al. This is an open access article distributed under the Creative Commons Attribution License, which permits unrestricted use, distribution, and reproduction in any medium, provided the original work is properly cited.

\begin{abstract}
The article presents the results of study of composition, structure and properties of three genetic types of serpentinites from Ural: developed by chromite-bearing ultrabasic rocks, by metamorphic zones of carbonate rocks and within the zone of weathering of ultrabasic rocks. The samples were selected from deposits, located along the Main Ural Fault the Paleozoic subduction zone (named GUR). Peculiarities of microstructure, chemical composition and properties of serpentinites formed in different geological conditions were investigated and their comparative study was held. Three groups of serpentinites with oriented and non-oriented structure, which formed by different protholites, were devided: mantle, lithosphere and crust.
\end{abstract}

Keywords: Ural; Serpentine; Subduction Processes; Petrophysical Properties; Velocity of Elastic Waves; Acoustic Emission

\section{Introduction}

Serpentine is a polygenic mineral which is forming in various geological conditions. Experimental studies show that various polymorphic modifications of serpentine are stable at different temperatures and pressures, and the antigorite is a stable phase under conditions of high pressures. The obtained experimental data show that elastic characteristics of minerals change depending on phase composition of serpentine [1]. These data show that serpentine can be the reference points of deep mantle and subduction processes [2]. That can be used for the interpretation of geophysical data and our knowledge of the deep structure of a lithosphere $[3,4]$. The strong seismic anisotropy observed in subducted slabs below the transition zone may be difficult to explain without strong preferential orientation in the mineralic phase in the slab. The $\mathrm{MgO}-\mathrm{Al}_{2} \mathrm{O}_{3}-\mathrm{SiO}_{2}-\mathrm{H}_{2} \mathrm{O}$ system is well known to be a simplified model system for the study of water transport and recycling into Earth's mantle via subduction processes [5]. Therefore any water bearing phase arising in P-T conditions compatible with the subducted slab is highly interesting for the comprehension of the complex geological processes determining the dynamical evolution of subducting zones. In this regard it is actual to study different serpentine from various deposits and detect features of the minerals formed at high pressures and temperatures.

\section{Objects of Researches}

For the purposes of this study we selected serpentinites, composing various mountain ranges in the area of GUR zone of the main Ural fault, which is the Paleozoic subduction zone. Serpentinized ultrabasic bodies are widely distributed on this territory. Two bands of ultrabasic intrusions (Figure 1), extending along the Urals are well known. There are Tagil-Magnitogorsk region and Central Urals. Many deposits of asbestos, chromium, nickel, and talc are associated with these intrusions.

GUR area was formed as a powerful sub-vertical depth disjunctive system during the late Paleozoic, at the collision stage of the Ural paleoocean closure. In the lateHerzin tectonic period multiple reducing of the mobile belt width occurred in area of GUR and convergence of structural-facial zones formed. Broad manifestation of the regional low-temperature and local high-pressure metamorphism are characterized this period. According to the deep geophysical research were established, that the Ural fault is a "border zone of mantle location at the junction of two ancient plates" [6]. It is believed that the structure of paleoocean sector of the Urals was formed with the participation of serpentine melange zones, which played the role of the lubricant for unloading of 


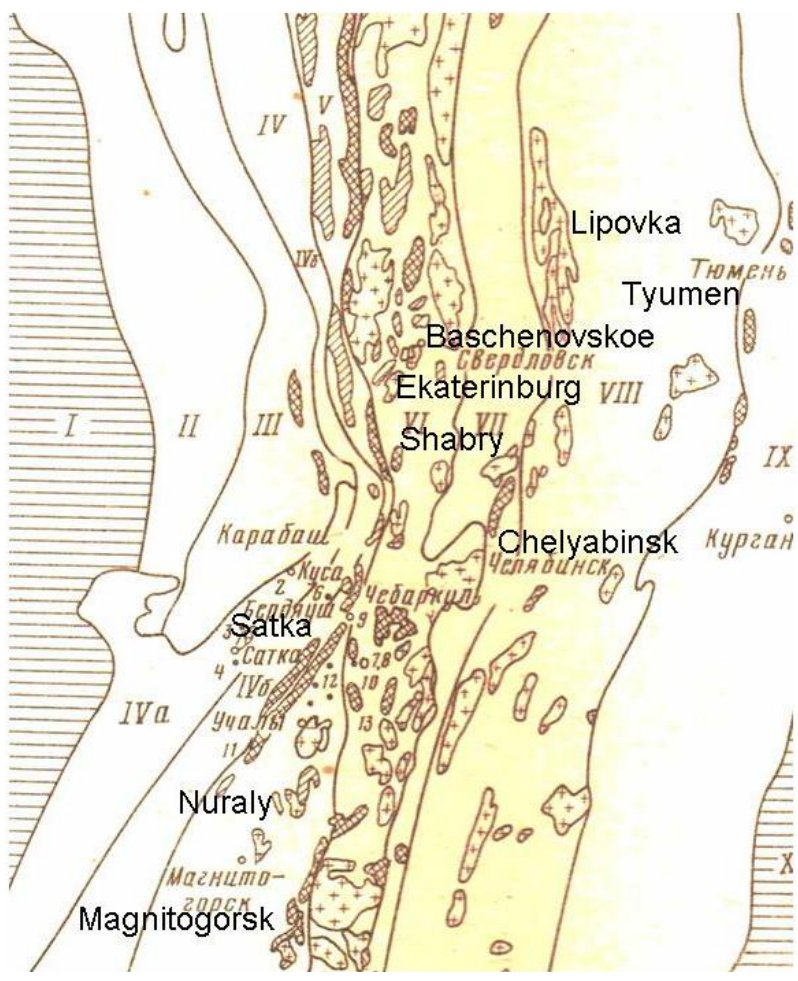

Figure 1. Main tectonic zones of the Middle and Southern Ural and places of the sampling locations [7]: I: Edge of the East-European platform; II: Preduralsky fore-deep; III: Western Urals area of folding; IV: Bashkir anti-clinorium; V: Tagil-Magnitogorsk trough; VI: East Ural uplift; VII: Eastern Urals basin; VIII: Zauralskiy uplift; IX: Tyumeno Kustanai-deflection; X: West Siberian plate.

the stress. In the Northern Urals GUR area is often a subvertical folding zone with fragments of serpentine melange. It divides paleooceanic and paleocontinental lithospheric blocks and is framed from the East with a strip of ultrabasic protrusions. Magnitogorsk synclinic zone is fixed with the complex of serpentinized dunite, peridotite, pyroxenite and gabbro. The bodies of the serpentinites and melange are widely distributed in the area of GUR and in the southern Urals (Figure 1).

Comparative studies were carried out on several genetically different types of serpentinites, which are the products of changes of rich in magnesium anhydrous minerals of magmatic and metamorphic rocks, composing the Ural ridge.

\subsection{Products of Replacement of Basic and Ultrabasic Rocks}

They develop by dunites, harzburgites and pyroxenites, composed by olivine, orthopyroxene and clinopyroxene.

The samples were collected from Nuralinsky dunite massif (sample N 8), from ultrabasic rocks of the Bazhenovsky deposit (sample N 10) and metasomatized chromite-bearing rocks (open pit near the town of Mag- nitogorsk, sample $\mathrm{N} \mathrm{14),} \mathrm{in} \mathrm{which} \mathrm{chromitites} \mathrm{form}$ separate, single, simple and complex veins.

The Nuraly ridge has a complex structure and consists of two petrographically heterogeneous parts, between which there is the powerful zone of serpentinite melange which crosses it and traces GUR. The Small Nuraly ridge is composed of layered pyroxenite complex rocks, which includes hornblendite-bearing gabbro, ortho- and clinopyroxenites and peridotites. The Grand Nuraly ridge is formed by the complex of ultramafic rocks: dunites, pyroxenites and spinel lherzolites. All rocks are serpentinized.

Bazhenovsky deposit of asbestos is represented by thick bodies $(20-300 \mathrm{~m})$, which extended for a considerable distance $(200-45 \mathrm{~m})$. It is established, that lizardite is earlier mineral in ores [8], and later one is chrysotile-asbestos, which forms clearly visible large veins (Figure 2).

\subsection{Products of Metasomatic Replacement of Magnesium Carbonate Rocks (Dolomite)}

These are formations with low iron content. Their massive variations are known as semi-precious stones - "noble serpentine", "ofiocalcite" (Figure 2).

They are characterized by metasomatic zoning [9]: unaltered rocks $\rightarrow$ serpentinized rocks $\rightarrow$ serpentinites $\rightarrow$ carbonatized (talk bearing) serpentinites $\rightarrow$ talc-carbonate-bearing rocks $\rightarrow$ quartz-carbonate-bearing rocks (listvenites). Serpentine formed during metamorphism of magnesial carbonate rocks are usually associated with deposits of talc and magnesite. We studied samples from Shabry talc deposit (sample N 9) and Satka magnesite deposit (sample N 7).

\subsection{Formation of Weathering Zone}

Serpentinites in weathering crusts are pseudomorphs of mica, which are formed in its replacement by vermiculite $\left(\mathrm{Mg}, \mathrm{Fe}^{2+}, \mathrm{Fe}^{3+}\right)\left[(\mathrm{Si} \mathrm{A} 1)_{4}, \mathrm{O}_{10}\right][\mathrm{OH}]_{2} \cdot 4 \mathrm{H}_{2} \mathrm{O}$ and montmorillonite $\left\{\mathrm{Mg}_{3}\left[\mathrm{Si}_{4} \mathrm{O}_{10}\right][\mathrm{OH}]_{2}\right\} \cdot \mathrm{p}\left\{\left(\mathrm{Al}, \mathrm{Fe}^{3+}\right)_{2}\left[\mathrm{~S}_{\mathrm{i} 4} \mathrm{O}_{10}\right]\right.$ $\left.[\mathrm{OH}]_{2}\right\} \cdot \mathrm{nH}_{2} \mathrm{O}$. Weathered lizardite has a lower content of $\mathrm{Mg}$ and higher of $\mathrm{Fe}, \mathrm{Al}, \mathrm{Cr}$, Ni. The so-called "sungulite" is a typical example of the serpentine in weathering zone.

Deposits of this type are known in the Urals in the area of Lake Sungul, near Kyshtym. Sample N 4 is obtained from the weathering zone of ultrabasic rocks in open pit Lipovka near Ekaterinburg (Figure 2(c)).

\section{Methods of Researchers}

The mineral composition of samples was studied by three different methods.

At the first stage we used the IR-spectroscopy (Figure 3). 


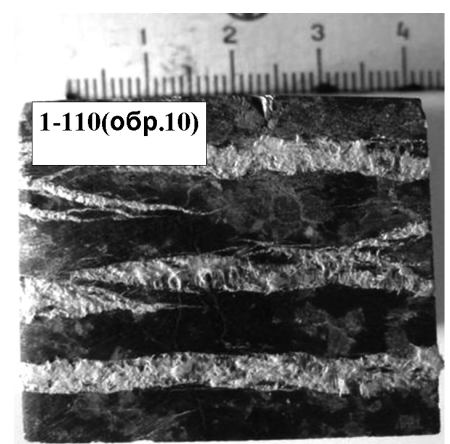

(a)

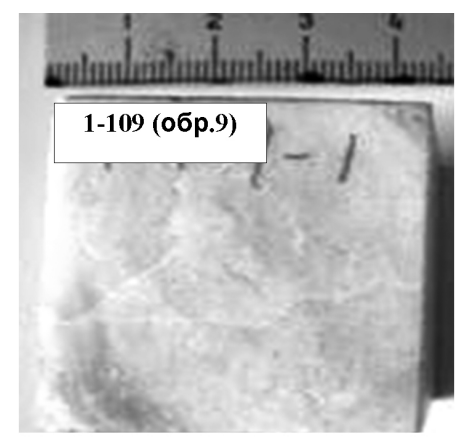

(b)

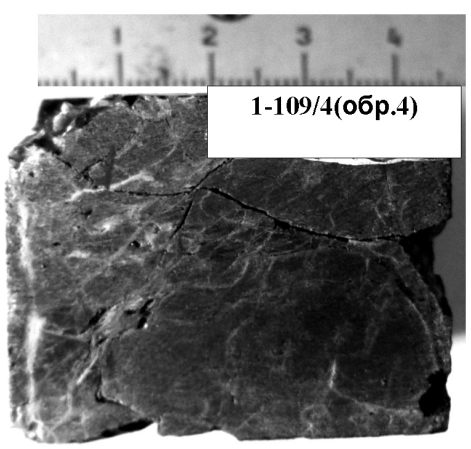

(c)

Figure 2. Overview and structural features of serpentinites: (a) white veins of the coarse-grained parallel microfiber chrysotile between which the green cryptocrystalline groundmass are observed with micro-veins of magnetite; (b) noble yellow serpentine from magnesian skarns with veins of asbestos in the fine-grained fibrous groundmass composed of micrograins of carbonate and separate large inclusions of calcite and lamellar serpentine; (c) Dark-colored serpentine with veins of opal (light) and inclusions of piroaurite- $\mathrm{Mg}_{6} \mathrm{Fe}_{2}(\mathrm{OH})_{16} \mathrm{CO}_{3} \cdot 4 \mathrm{H}_{2} \mathrm{O}$ with a fine-grained structure and irregularlyspotted impregnation of magnetite.

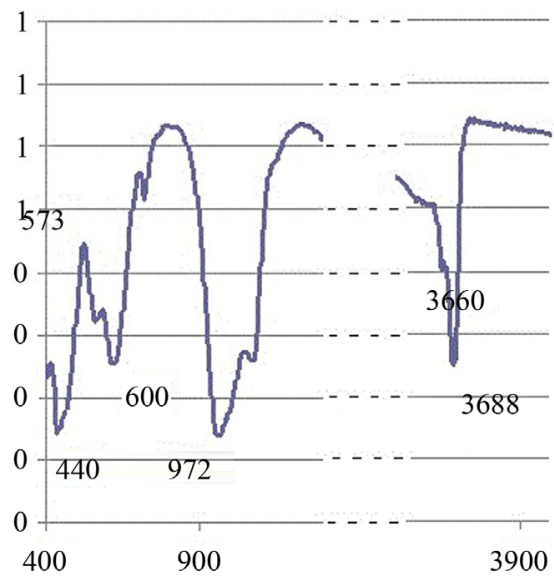

(a)

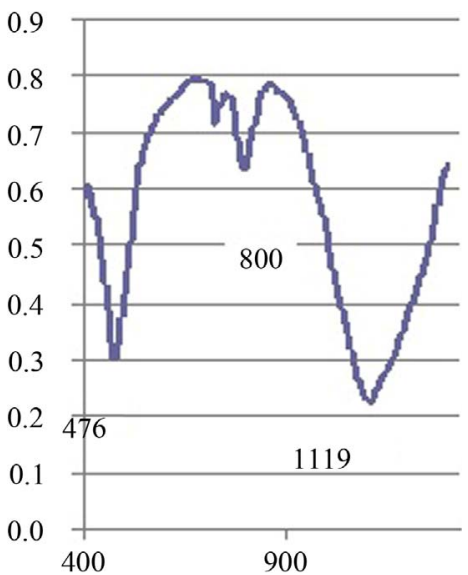

(b)

Figure 3. IR spectra of samples of serpentinite: (a) lizardite prevails (samples 8 \& 10); (b) clinochrysotile + opal prevails (samples $4 \&$ 14).

Spectra recording was carried out by means of paste in vaseline oil with the help of the "MONITORING-Fourie-IR-spectrophotometr" device. The antigorite has valence vibrations of the Si-O diagnostic bands at 1205 $1210 \& 985-995 \mathrm{~cm}^{-1}$, the chrysotile has a wide weak band $1015-1020 \mathrm{~cm}^{-1}$, the lizardite has a band $1050-$ $1060 \mathrm{~cm}^{-1}$. Lizardite and chrysotile differ in the form of the band $440-450 \mathrm{~cm}^{-1}$ and in the intensity of the band $570 \mathrm{~cm}^{-1}$. For minerals rich in iron and aluminum translation of the bands to the low-frequency area were observed.

At the second stage we used the thermal analysis of the samples on the derivatograph device Q-1500. The heating was carried out in the temperature range from $25^{\circ} \mathrm{C}$ to $1000^{\circ} \mathrm{C}$. The main endothermic effect is observed in the range of temperatures between $670^{\circ}$ and $730^{\circ}$. It is associated with the release of constitutional water and the destruction of the crystal structure of the mineral. Exothermic effect is observed in the range of $790^{\circ} \mathrm{C}-810^{\circ} \mathrm{C}$. It is associated with the transformation of serpentine to forsterite. Its intensity increases in the series: antigorite-lizardite-chrysotile. Small exothermic effect is also noticed between $1100^{\circ} \mathrm{C}$ and $1300^{\circ} \mathrm{C}$. It is associated with the crystallization of enstatite (magnesium pyroxene). Endothermic effect at low temperatures $\left(100^{\circ}-180^{\circ}\right)$ is associated with the release of the adsorption water, and at $\mathrm{T}<150^{\circ} \mathrm{C}$ it is reversible.

The destruction of metastable phases, formed during the dehydration of mineral and removal of residual hydroxyls, can also be manifested in the form of additional endothermic effect. Entering of iron into the serpentine reduces the temperature of the basic exothermal effect. In heating up to $400^{\circ} \mathrm{C}$ in the conditions of high partial oxygen pressure transformation of serpentines into talc occurs.

In the third stage X-ray diffractometry analysis on 
DRON-3 device in the range from 1 up to 60029 was performed in the following mode: radiation $\mathrm{Cu}$, filtered $\mathrm{Ni}$, voltage of the tube $30 \mathrm{kV}$, the strength of current 20 A. Decoding of the X-ray spectra was performed in automatic mode. Characteristic line of all serpentine is 001 at $7.3 \AA$. Lizardite and chrysotile give a strong line 060 about $1.535 \AA$, while no other strong lines near this area are detected. The antigorote has more lines on X-ray spectra and they are clearer. Next to the reflex 060 at $1.541 \AA$ there are reflexes in the 1.563 and $1.534 \AA$. The most common polytypes of chrysotile and lizardite are best distinguished in the range of $2.60-1.96 \AA$. Lizardite $1 \mathrm{~T}$ has no lines 203 and 205.

The chemical composition of the serpentinite were studied by the method of electron-probe analysis on the device CAMEBAX with accelerating voltage of $15 \mathrm{kV}$ and current probe $30 \mathrm{~A}$. We used natural minerals and artificial compounds as a standard samples: $\mathrm{Mg}$-olivine, $\mathrm{Si}, \mathrm{Al}, \mathrm{Fe}-$ hornblende, $\mathrm{Ti}-\mathrm{MnTiO}_{3}, \mathrm{Ni}-\mathrm{NiO}, \mathrm{Cr}-\mathrm{Cr}_{2} \mathrm{O}_{3}$. A total of 32 complete analysis "at the point" were executed.

Structural and petrophysical analysis was carried out on transparent polished sections with traditional optical-microscopic methods with the use of "OLYMPUS" microscopes.

The micro-structural features of the serpentinites were studied in the M.V. Lomonosov Moscow State University laboratory of the local methods on micro-probe complex at the basis of the scanning electronic microscope "Jeol JSM-6480LV". Processing of results was performed with the help of a professional licensed software "SEM Control User Interface", version 7.11 (Jeol Technics LTD). The samples were studied under gold plating with the thickness of about $30 \mathrm{~nm}$. Scanning electron images were obtained in secondary electrons at an accelerating voltage of $15 \mathrm{kV}$ and a current probe of $11 \mathrm{nA}$.

Petrophysical properties were studied with standard and unique methods. Were measured: $\rho \cdot \mathrm{g} / \mathrm{cm}^{3}-$ bulk density of the rock, $\rho_{\mathrm{S}} \cdot \mathrm{g} / \mathrm{cm}^{3}$ - the density of the solid phase with all the components, $\mathrm{n} \%$ - total porosity, $\mathrm{W}_{\mathrm{g}} \%$ - hygroscopic moisture, $\mathrm{V}_{\mathrm{p}} \mathrm{km} / \mathrm{sec}$ - velocity of a longitudinal wave, $V_{\mathrm{s}} \mathrm{km} / \mathrm{s}$ is the speed of the shear wave, $U_{\text {nit }}$ $10^{3} \mathrm{MPa}$ - the dynamic modulus of elasticity, $\mu_{\mathrm{d}}$ - dynamic Poisson's ratio, $\mathrm{K}_{\mathrm{A}}$ - anisotropy factor, $\mathrm{R}_{\mathrm{S}} \mathrm{MPa}-$ uniaxial compressive strength.

Microhardness of serpentine was conducted on the LOMO device PMT-3M. The measurements were carried out on samples of artificial press-fittings of serpentine. We measured the imprint of the diamond pyramid on the sample under a load of 20 - $100 \mathrm{~g}$ for 10 seconds.

Mineral density of objects was measured by several independent methods. The density of small pieces of irregular shape was determined by weighing in air and in water. In addition, density was calculated for the samples of regular shape by measuring the mass and volume. These data were supplemented by determining the density of the solid phase with the original device, invented at the Department of Engineering and Environmental Geology of the Lomonosov Moscow State University [PELA-2]. The device uses the weighting powder of rocks (size of particles $-0.25 \mathrm{~mm}$ ) compressed to standard volume under vacuum. The calculation of the elastic module and Poisson's ratio was carried out using standard formulas of the theory of elasticity on the basis of values of density $(\rho)$ and velocity of longitudinal $\left(\mathrm{V}_{\mathrm{p}}\right.$, $\mathrm{km} / \mathrm{s})$ and shear $\left(\mathrm{V}_{\mathrm{s}}, \mathrm{km} / \mathrm{s}\right)$ waves.

Determination of velocity of longitudinal and shear waves was carried out on standard device with emitters and receivers of the waves in the frequency range 250 $\mathrm{KHz}$. Cubic samples with a volume $9-16 \mathrm{~cm}^{3}$ were studied. 2 - 3 such samples were prepared for every probe and the measurements were carried out in two perpendicular directions. The thin plane-parallel plates $(5 \times 40$ $\mathrm{mm})$ were made from the same samples. For these plates determination of velocity of longitudinal and shear waves was carried out in the International Laser Center of Moscow State University using the device UDL-2M (laser ultrasound flaw detector)-“Geoskan-02M”. On setup "GEOSCAN-02M" the examinations can be carried out in the transmitted waves mode. Measurements were carried out through the $5 \mathrm{~mm} \& 40 \mathrm{~mm}$ layers of rock. The rates were determined for the part of the sample, which was the most homogeneous and don't has a cracks. The work of the "GEOSCAN-02M" based on thermo-optical excitation of short powerful ultrasonic pulses and spectrum analysis of the signals passed though investigated samples [10].

A study of the acoustic emission (AE) properties of serpentinite under uniaxial compression was conducted. Uniaxial compression test with simultaneous measurement of acoustic emission (AE) was carried out on a press CDM-2. Obtained and analyzed the first results on AE in condition of the constant rate $(100 \mathrm{~kg} / \mathrm{min})$ of loading for the cube samples with a size $3-4 \mathrm{~cm}$. Maximum values of the amplitude and the energy of the signal, the frequency spectrum, the activity and the intensity of the AE on frequency bands, the speed of the occurrence of the events were recorded. Acoustic measurements were carried out using a 4-channel system of acoustic emission monitoring VTS 1008. The signal coming from the sample (pulses of duration $10^{-4}-10^{-8} \mathrm{sec}$ ), through piezoelectric transducer (measuring time for record $1 \mathrm{~ms}$ ) and the amplifier is supplied to the processing unit for continuous comparison of the absolute values of the incomeing signal with the threshold value of discrimination (58 $\mathrm{dB})$. In case if the absolute value of the current specified threshold is exceeded, digital recording of the signal be- 
gins. The following event parameters are calculated: $N^{-}$ the number of $\mathrm{AE}$ events in 1 second, $\Sigma \hat{\mathrm{N}}$ - the sum of events over time $t$, the average value of the maximum amplitude and the energy of AE signals in 1 second, the frequency spectrum. The task of the researches was to identify the dependant of the acoustic emission from the structural parameters of serpentinites from different paleosubducting zones. The most informative parameters of $\mathrm{AE}$ of rocks are: active of the AE (it can be calculated on the base of slope of the curve of averaged velocity of the $\mathrm{AE}$ events); the intensity of the $\mathrm{AE}(\Sigma \mathrm{N}=\mathrm{f}(\mathrm{t}))$ and distribution of the impulses over the frequency band.

\section{The Results of the Study}

According to spectroscopic data we divided the serpenttinites into 3 groups:

Group 1: samples from Nurali (N 8) and Bazhenovsky (N 10). In these samples a prevailing phase is lisardite with absorption strip of 3669 and $3688 \mathrm{~cm}^{-1}$.

Group 2: samples of light green (N 9) and yellow (N 7) noble serpentine. In these samples a prevailing phase is antigorite.

Group 3: samples of dark serpentine (N 4, 14). In these samples a prevailing phase is clinohrysotile and a lot of water-bearing sulphate phase appear as impurity.
The results of micro-beam analysis showed that the studied samples of serpentine have different content of $\mathrm{Al}$ and $\mathrm{Cr}$ impurities (Table 1).

Three groups are clearly subdivided depending on the content of Al.

1) high $\mathrm{Al}\left(\mathrm{N} 10,4,8 ; \mathrm{Al}_{2} \mathrm{O}_{3}>0.6\right.$ mac.\%).

2) low $\mathrm{Al}\left(\mathrm{N} 9,7 ; \mathrm{Al}_{2} \mathrm{O}_{3}<0.1 \mathrm{mac} \%\right.$ ).

3) middle $\mathrm{Al}\left(\mathrm{N} \mathrm{14} ; \mathrm{Al}_{2} \mathrm{O}_{3}\right.$ from 0.3 up to 0.5 mac.\%). According to the content of chromium and nickel there are also clearly distinguished three groups.

1) high $\mathrm{Cr}\left(\mathrm{N} 10 ; \mathrm{Cr}_{2} \mathrm{O}_{3}>0.45\right.$ mac.\%).

2) middle $\mathrm{Cr}\left(\mathrm{N} 8 ; \mathrm{Cr}_{2} \mathrm{O}_{3}\right.$ from 0.1 up to 0.4 mac.\%).

3) low $\mathrm{Cr}\left(\mathrm{N} 7,9,8,14 ; \mathrm{Cr}_{2} \mathrm{O}_{3}<0.05\right.$ mac.\%).

Two series of samples were studied by the SEM method. Samples of the first series were finely splinted $(<0.1 \mathrm{~mm})$ materials (powders) deposited on a doublesided carbon film, mounted on glass.

The second series of samples was represented by large (3 - $5 \mathrm{~mm}$ ) debris, fixed on an aluminum holder with epoxy. The following key parameters were recorded: features of a surface of splinters and fragments, microstructure of a surface, size and a form of the separate particles, existence or absence of prevailing orientations. As a result of the carried-out researches essential differences of the studied parameters for the selected samples were revealed (Figure 4):

Table 1. The results of micro-beam analysis of the serpentinites.

\begin{tabular}{|c|c|c|c|c|c|c|c|c|}
\hline Number & $\mathrm{MgO}$ & $\mathrm{SiO}_{2}$ & $\mathrm{Al}_{2} \mathrm{O}_{3}$ & $\mathrm{TiO}_{2}$ & $\mathrm{FeO}$ & $\mathrm{NiO}$ & $\mathrm{Cr}_{2} \mathrm{O}_{3}$ & Zum. \\
\hline 10 & 40.21 & 41.93 & 0.61 & 0.02 & 1.72 & 0.31 & 0.46 & 85.28 \\
\hline 9 & 40.82 & 42.66 & 0.03 & 0.01 & 1.18 & 0.01 & 0.03 & 84.75 \\
\hline 14 & 41.44 & 42.38 & 0.38 & 0.01 & 1.54 & 0.25 & 0.02 & 86.03 \\
\hline 4 & 39.71 & 41.82 & 0.68 & 0.03 & 3.09 & 0.18 & 0.13 & 85.64 \\
\hline $8-1$ & 40.89 & 42.71 & 0.67 & 0.04 & 3.12 & 0.52 & 0.11 & 88.06 \\
\hline $8-2$ & 40.61 & 42.17 & 0.93 & 0.03 & 2.35 & 0.33 & 0.39 & 86.82 \\
\hline $7-19$ & 40.59 & 44.76 & 0.03 & 0.02 & 0.18 & 0.01 & 0.06 & 85.64 \\
\hline
\end{tabular}

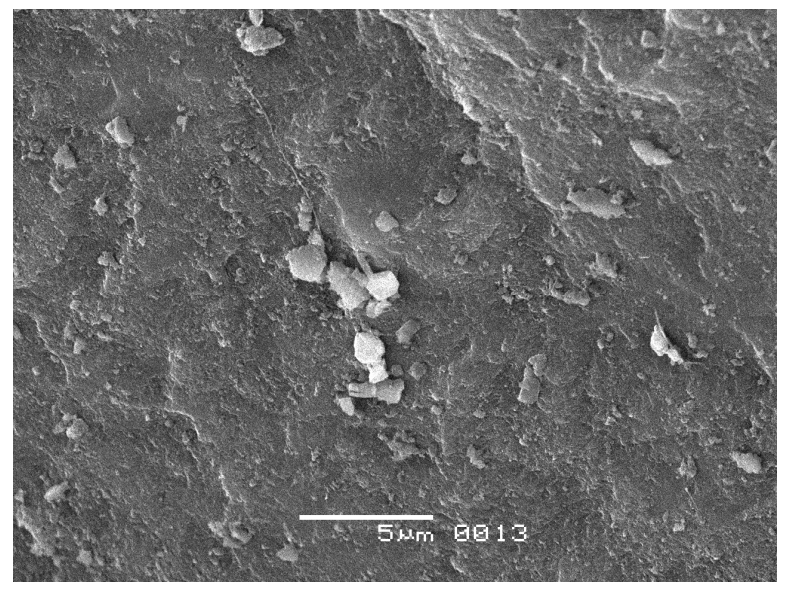

(a)

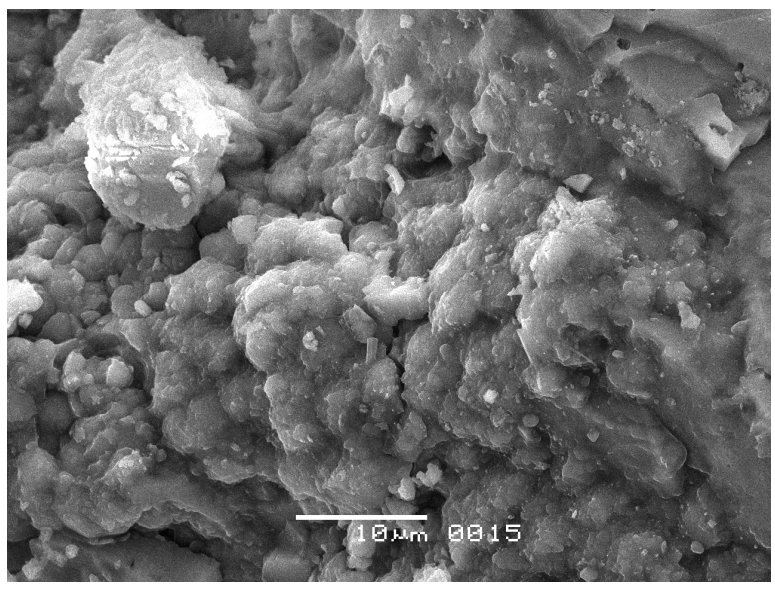

(b)

Figure 4. The features of the microstructure of the serpentinite: (a) smooth surface of the particles; (b) the presence of carbonate inclusions in lizardite matrix. 
- Presence of microlayers of asbestos of various thickness (N 8, 10).

- Smooth structure of a surface without a flokulation processes $(\mathrm{N} \mathrm{14}, 7,4)$ and with microlamination $(\mathrm{N}$ $10)$.

- Wrong form of the fragments of the rocks with shelled-likely surfaces (N 8).

- Presence of mineral inclusions of the isometric form in lisarditic matrix (N 10,9).

- The rough "fragmentary" form of particles, which is characteristic for saponitic minerals (N9).

- Lisardite and Hrysotile don't form an oriented texture. They form a complex fibrous-plates structure (N 10) with prevalence of antigoritic forms (N 14, 8).

- Lizardite' particles sizes in genetically diverse samples are different: some are seen with magnification by 700 - 2500 times, while other particles are visible when magnified by 10,000 - 30,000 times.

Petrographic study of serpentinite revealed peculiarities of microstructure of different rock groups. Inclusions of various minerals were obtained in serpentinites (Figure 5): the opal in sample $\mathrm{N} 4$, olivine in samples $\mathrm{N} 8$ \& $\mathrm{N} 14$, plagioclase in sample $\mathrm{N} 9$ and carbonates in sample N 7.

Sample N 8. Pseudomorphs after olivine were established. Cracks developed within the grains are clearly visible. Edges of pseudomorphs are marked with magnetite, precipitated in the process of serpentinization by the reaction of $2(\mathrm{Mg}, \mathrm{Fe})_{2} \cdot \mathrm{SO}_{4}+\mathrm{H}_{2} \mathrm{O} \Longrightarrow \mathrm{Mg}_{3} \mathrm{Si}_{2} \mathrm{O}_{5}$ $(\mathrm{OH})_{2}+\mathrm{Fe}_{3} \mathrm{O}_{4}$. Zonal structure of pseudomorphs can be seen at high magnification. The central parts of pseudomorphs are composed of laminary particles, and the edging parts of tubular ones.

Sample N 10. Polymineral composition and microcracks are clearly distinguished in the irregularly-grained rock. The vein structure is obtained; the remains of the grains of the primary silicates are seen. Their boundaries with serpentine are corroded, and many grains of Fe ox- ides which formed in such a substitution are established.

Sample N 7. Equigranular structure of the groundmass of the rock is established. Lamellar form of individual serpentine grains up to a size of 1 micron is observed at high magnification.

Sample N 14. The serpentine pseudomorphs after pyroxene grains are observed. Relics of cleavage of the primary mineral at $90^{\circ}$ are clearly visible. We revealed parallel columnar structure of the serpentine grains, in a mass of which there are veins filled with micaceous material. Unevenly granular structure of the rock is characteristic: larger serpentine laths and grains with high interference color are seen in microcrystalline groundmass. Twinned structure of carbonates micro inclusions is observed at higher magnification.

Sample N 9. The contact zone of carbonates and serpentine is traced. Coarse grains of piroaurite

$\left(\mathrm{Mg}_{6} \mathrm{Fe}_{2} \cdot(\mathrm{OH})_{16}\left[\mathrm{CO}_{3}\right] \cdot 4 \mathrm{H}_{2} \mathrm{O}\right)$ with high interference colors are identified in a fine-grained serpentine groundmass. The last contact with opal, and a numerous fluid inclusions were established in the opal grains.

Sample N 4. There was found an equigranular structure of the microcrystalline groundmass of serpentinite. Powerful secondary iron accumulation along an intense macro- and micro-fractures is manifested. Abundant inclusions of the ore minerals underline the high content of iron of the primary protolith, and secondary iron accumulation connected with the replacement of the primary Mg-Fe silicates.

The physical properties of the studied rocks are controlled by the phase composition and structure of the samples. The study results of the petro-physical parameters are presented in Table 2. Chief among them-bulk and mineral density of the rock $\left(\rho, \rho_{\mathrm{S}} \cdot \mathrm{g} / \mathrm{cm}^{3}\right), \mathrm{n} \%$ - total porosity, $\mathrm{W}_{\mathrm{g}} \%$ - hygroscopic moisture, $\mathrm{H}$-microhardness, $\mathrm{V}_{\mathrm{p}} \mathrm{km} / \mathrm{s}$ and $\mathrm{V}_{\mathrm{s}} \mathrm{km} / \mathrm{s}$ - the speed of longitudinal and shear waves, $\mathrm{K}_{\mathrm{A}}$ - anisotropy factor; and, in addition, other deformation characteristics: $\mathrm{E}_{\mathrm{d}} \cdot 10^{3} \mathrm{MPa}$ - the dy-

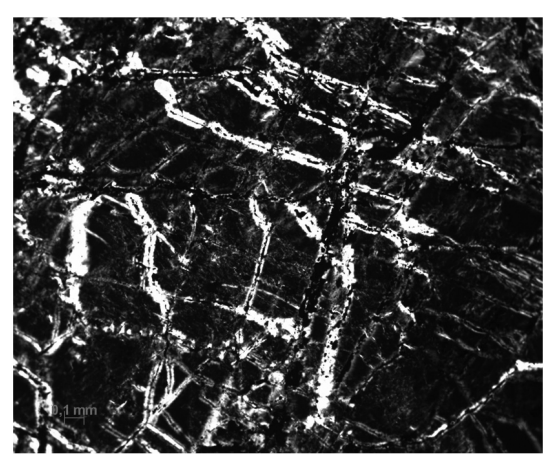

(a)

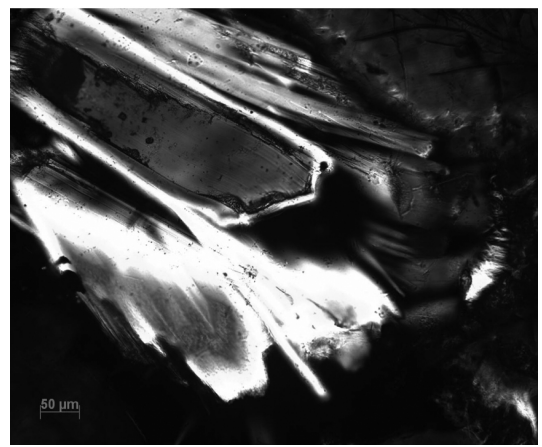

(b)

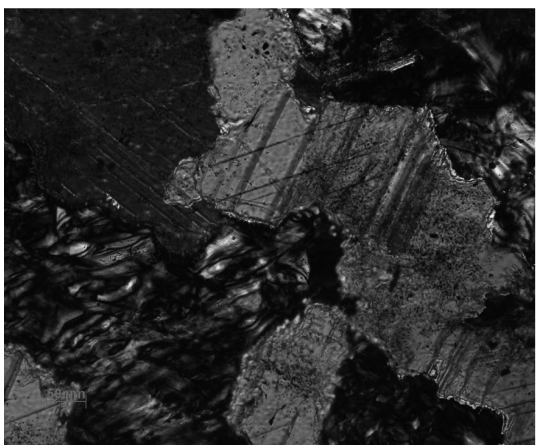

(c)

Figure 5. Structural and petrography features of the studied serpentinites: (a) micro veins of the chrysotile (sample 14); (b) inclusions of carbonates; (c) pseudomorphs after olivine and pyroxene (sample 8). 
Table 2. Genetic groups, composition and petrophysical properties of the studied serpentinite.

\begin{tabular}{|c|c|c|c|c|c|c|}
\hline Sample N & 8 & 10 & 9 & 7 & 4 & 14 \\
\hline Deposit & Nuraly & Baschenovo & Shabry & Satka & Lipovka & Sungul \\
\hline Structure & Undirected & Oriented & Undirected & Oriented & Undirected & Oriented \\
\hline Composition & \multicolumn{2}{|c|}{$\mathrm{Al}_{2} \mathrm{O}_{3}>0.6 \%, \mathrm{Cr}_{2} \mathrm{O}_{3}>0.45 \%$} & \multicolumn{2}{|c|}{$\mathrm{Al}_{2} \mathrm{O}_{3}<0.1 \%, \mathrm{Cr}_{2} \mathrm{O}_{3}<0.05 \%$} & \multicolumn{2}{|c|}{$\mathrm{Al}_{2} \mathrm{O}_{3}=0.3 \%-0.5 \%, \mathrm{Cr}_{2} \mathrm{O}_{3}<0.05 \%$} \\
\hline Protholite & \multicolumn{2}{|c|}{ Ultramaphic, mantle } & \multicolumn{2}{|c|}{ Metasomatic carbonates, crust } & \multicolumn{2}{|c|}{ Maphic, crust } \\
\hline Hardness $\left(\mathrm{H}, \mathrm{G} / \mathrm{mm}^{2}\right)$ & 816.3 & 21.0 & 111.1 & 25.5 & 625.0 & 132.2 \\
\hline Bulk density $\left(\rho, \mathrm{G} / \mathrm{sm}^{3}\right)$ & 2.65 & 2.43 & 2.40 & 2.58 & 2.65 & 2.66 \\
\hline Mineral density $\left(\rho, \mathrm{G} / \mathrm{sm}^{3}\right)$ & 2.76 & 3.04 & 2.78 & 3.02 & 2.66 & 3.10 \\
\hline Porosity, n, \% & 4.0 & 20.0 & 13.7 & 14.6 & 0.4 & 14.2 \\
\hline Hygroscopic moisture, W \% & 0.33 & 0.40 & 0.29 & 0.40 & 4.0 & 0.36 \\
\hline $\begin{array}{c}\text { Speed of longitudinal waves } \\
\left(\mathrm{V}_{\mathrm{p}}, \mathrm{km} / \mathrm{sec}\right) \text { (min-max mediate) }\end{array}$ & $\begin{array}{c}5.4-6.7 \\
5.8\end{array}$ & $\begin{array}{l}3.2-5.4 \\
4.55\end{array}$ & $\begin{array}{l}5.7-7.3 \\
6.38\end{array}$ & $\begin{array}{l}3.5-5.0 \\
4.23\end{array}$ & $\begin{array}{l}1.2-4.1 \\
2.96\end{array}$ & $\begin{array}{l}4.5-5.0 \\
4.75\end{array}$ \\
\hline $\mathrm{K}_{\mathrm{A}}$ - anisotropy factor $\left(\mathrm{V}_{\mathrm{p}} / \mathrm{V}_{\mathrm{s}}\right)$ & $\begin{array}{l}1.96 \\
1.75 \\
2.07\end{array}$ & $\begin{array}{c}2.5-1.9 \\
1.1 \\
2.27\end{array}$ & $\begin{array}{c}2.6 \\
1.7 \\
2.47\end{array}$ & $\begin{array}{l}1.73 \\
1.86 \\
2.06\end{array}$ & $\begin{array}{c}1.75 \\
2.0 \\
1.74\end{array}$ & $\begin{array}{l}2.92 \\
2.14 \\
2.06\end{array}$ \\
\hline Dynamic elastic modulus $\left(\mathrm{E}_{\mathrm{d}} \cdot 10^{3} \mathrm{MPa}\right)$ & 58 & 28 & 45 & 31 & 14 & 40 \\
\hline Dynamic Poisson’s ratio $\left(\mu_{\mathrm{g}}\right)$ & 0.34 & 0.37 & 0.40 & 0.33 & 0.35 & 0.33 \\
\hline $\begin{array}{l}\text { Uniaxial compressive strength } \\
\qquad\left(\mathrm{R}_{\mathrm{S}} \mathrm{MPa}\right)\end{array}$ & 64 & $22-28$ & 93 & $19^{*}, 55$ & $32-49$ & \\
\hline
\end{tabular}

the value of the sample with the cracks.

namic elastic modulus, $\mu_{\mathrm{g}}$-dynamic Poisson's ratio; $\mathrm{R}_{\mathrm{S}}$ $\mathrm{MPa}$ - uniaxial compressive strength. Table 2 shows the studied parameters and their values in the rocks averaged out of the measurements of 3 - 4 samples for each genetic type.

Value of microhardness of the studied samples varies very strongly. The maximum hardness (816 - 1111 $\mathrm{g} / \mathrm{mm}^{2}$ ) has noble light green serpentinite (ophiocalcite). The minimum hardness $\left(21 \mathrm{~g} / \mathrm{mm}^{2}\right)$ has green serpentine with clearly distinguishable large streaks of chrysotileasbestos from the Bazhenovsky deposit of the Urals and yellow noble serpentine with chrysotile-asbestos streaks from magnesian metasomatic carbonates.

Analysis of the table shows that the bulk density of the samples $8,7,4,14$ from different genetic groups changes slightly and is close to values of the density from the literature data (2.50 - 2.55 - chrysotile, 2.5 - 2.7 - antigorite, 2.55 - 2.6 - lizardite [11-13]. The minimum volume density $\left(2.4 \mathrm{~g} / \mathrm{sm}^{3}\right)$ has a sample 4-brown serpentine with the opal and numerous fluid inclusions. The maxi- mum volume density $\left(2.87 \mathrm{~g} / \mathrm{sm}^{3}\right)$ has a sample 14-black serpentine from metasomatic chromite-bearing ultramaphic rocks. The density is reduced in the samples 10 and 9 due to the presence of micro inclusions of mica and carbonates. The increased density of the solid rock phase in the studied samples is determined by the presence of magnetite.

Open porosity in the unaltered serpentinites of sample 8 corresponds to the primary porosity of the solid rock.
For example, the density of basalts are ranged from 1.34 up to $5.6 \%$, it is increased for kimberlites (containing serpentine and carbonates) up to $13 \%-25 \%$, and in the samples from the weathering zone- up to $11.4 \%-41.2 \%$ [14-16]. In our samples it increases in rocks that are converted in metasomatic processes of carbonate rocks (sample 7,9), amounting up to $14.6 \%$. The maximum values are found in samples 10, which are determined by the presence of hollow spaces in the asbestos tubular grains. Sample 4 showed a significant increase of hygroscopic moisture, which may be due to the presence of a significant amount of opal.

The maximum velocity values of longitudinal waves $\left(\mathrm{V}_{\mathrm{p}}\right)$ is usually observed in the direction which is parallel to the mineral orientation of the rock. If this value is measured in the abovementioned direction, than the value of Eg reaches its maximum. The minimum velocity of the elastic waves $\left(\mathrm{V}_{\mathrm{p}}=1.2 \mathrm{~km} / \mathrm{sec} ; \mathrm{V}_{\mathrm{s}}=0.6 \mathrm{~km} / \mathrm{sec}\right)$ has a sample 4-clinohrysotile with the opal. This sample has a minimum value of the modules of the deformations $(1.0$ and $2.6 \mathrm{GPa})$. The maximum velocity of the elastic waves $\left(\mathrm{V}_{\mathrm{p}}=4.5 \mathrm{~km} / \mathrm{sec} ; \mathrm{V}_{\mathrm{s}}=2.6 \mathrm{~km} / \mathrm{sec}\right)$ has a sample 9 -antigorite from noble green ophiocalcite. This sample has a maximum value of the modules of the deformations (17.3 and 43.6 GPa).

Factor of anisotropy was estimated at both speeds and adjusted for 2 directions of measurement. We can see from Table 3, that the sample 10 and sample 4 are significantly anisotropic. The first has an oriented layered 
structure and the second is intensively fractured. The influence of the macro- and micro-cracks on the value of $\mathrm{V}_{\mathrm{p}}$ is clear (according to the velocity analysis, measured on the basis of 5 and $40 \mathrm{~mm}$ ). Maximum reduction of this parameter (by 3 times) occurs in a highly ferruginous and highly cracked sample 4 . Decrease of velocity by almost 2 times is noted in sample 10. This is due to the substantial attenuation of waves in asbestos veins. The velocity of the seared wave $\mathrm{V}_{\mathrm{s}}$ are maximally reduced for $32 \%$ for the same fractured species.

Special attention was paid to the sample 10, containing white layers of asbestos of 1 - $4 \mathrm{~mm}$ thick. Measurements were carried out for $5 \mathrm{~mm}$ plate in three selected "dark" layers and in one selected white layer. Characteristic diameter of the probe ultrasonic beam was $2 \mathrm{~mm}$. The dependence of the attenuation constant was measured in the frequency ranging from 0.3 to $20 \mathrm{MHz}$. For the three "dark" samples attenuation was increasing from $0.5 \mathrm{~cm}^{-1}$ to $6.5 \mathrm{~cm}^{-1}$ with increased frequency.

For the "white" layers attenuation in the same frequency range increased by 3 times in the low frequencies and by 1, 3 times in the high ones. However, the velocities of longitudinal waves changes little and were $5100 \pm$ $50 \mathrm{~m} / \mathrm{s}$ in the "dark" layers and $4900 \pm 50 \mathrm{~m} / \mathrm{s}$ for the "white" one. This allows to operate with integrated characteristics of the longitudinal waves velocities in general for the whole rock.

\section{Discussion of the Results}

The differences in the phase and chemical composition of the studied samples, as well as differences in their properties suggest that the geological conditions of their formation must also be different. Literature review of the mantle minerals peculiarities [17-20], shows that the high chromium content in the silicates (garnet, olivine, pyroxene) are characteristic for high-pressure paragenesis. Based on the fact that our serpentinites inherit the chemical composition of the primary source minerals, we can assume that they are formed by different protoliths.

Chemical composition was detected and serpentinites were divided into following groups according to the Al and $\mathrm{Cr}$ content:

- N10, 8 - high $\mathrm{Al}\left(\mathrm{Al}_{2} \mathrm{O}_{3}>0.6\right.$ weight \%); high and middle $\mathrm{Cr}\left(\mathrm{Cr}_{2} \mathrm{O}_{3}>0.45\right.$ weight $\%$ and from 0.1 up to 0.4 weight $\%$ ).

- $\mathrm{N}$ 9, 7 - low $\mathrm{Al}\left(\mathrm{Al}_{2} \mathrm{O}_{3}<0.1\right.$ weight \%) and low $\mathrm{Cr}$ $\left(\mathrm{Cr}_{2} \mathrm{O}_{3}<0.05\right.$ weight \%).

- $\mathrm{N} 14$ - middle $\mathrm{Al}\left(\mathrm{Al}_{2} \mathrm{O}_{3}\right.$ from 0.3 up to 0.5 weight $\left.\%\right)$ and low $\mathrm{Cr}\left(\mathrm{Cr}_{2} \mathrm{O}_{3}<0.05\right.$ weight \%).

Serpentinites of the first group have an ultramaphic protholites and formed at the mantle depth. Serpentinites of the second group has a carbonate protholites and formed near the surface of the Earth. Serpentine of the third group has a maphic protholite and formed at the lithosphere (Table 2).

Petrographic studies show that the examined samples differ not only in the mineral and chemical composition, but also on the texture-structural features. Two groups of objects can be distinguished among them. The first group -samples with the equigranular microstructural structure, in which the prevailing phase is lizardite or antigorite. The second group-samples, which is characterized by the presence of oriented cracks, microveins filled with asbestos and inclusions of non-silicate phases (carbonates, opal). Naturally these structural and textural differences affect the physical properties of the rocks.

The values of elastic constants are directly related to the degree of continuity of rocks, size of crystal grains, mineral composition, degree of metamorphism and depth of formation (Table 2)

We compared our results with literary data [2]. Values of $\mathrm{V}_{\mathrm{p}}$ for our samples are close to the values received earlier for aggregates of antigorite. Values of $\mathrm{V}_{\mathrm{s}}$ for our samples are much lower, than ones measured earlier. Anisotropy also is different. Especially significant differences are observed for samples 4 and 10. They are associated with presence of the opal (4) and an abundance of streaks of chrysotile-asbestos in a lizarditic matrix (10). Physical parameters of the antigorite-bearing samples ( 9 and 7) are closest to the constants received by Brillouin spectroscopy method. Thus, these data suggest that it is not always correct to compare the values of the physical parameters which are obtained from singlecrystal experiments with measurements of natural objects, which are taken for huge amounts of rock.

The Poisson's ratio reflects the deformation properties in the orthogonal direction and its value is largely determined by the type of predominant mineral in the rock. It should be noted that the values of $\mu_{\partial}(0.3-0.4)$, obtained for the serpentinites are close to the values of this parametr for the typical plastic rocks (clays and loam soil). This is consistent with the notion that serpentines acted as "lubricating grease" during tectonic movements along faults in the GUR area and they commonly accompany these tectonic structures.

Structural-textural features of rocks, as well as their mineral composition were formed in the course of a long and complex geological history of the Urals region. The conducted reconstructions [21,22] show that in the Paleozoic time, starting from the Silurian, the zone of lithospheric plate shifts was formed in the area of GUR (Figure 6). As a result of these tectonic movements structures of the Western block were immersed, subducted under the structures of the Eastern block. Studied samples were collected in different regions of the Ural ridge (Figure 2) and therefore have experienced different tectonic strain. These differences had to affect their prop- 


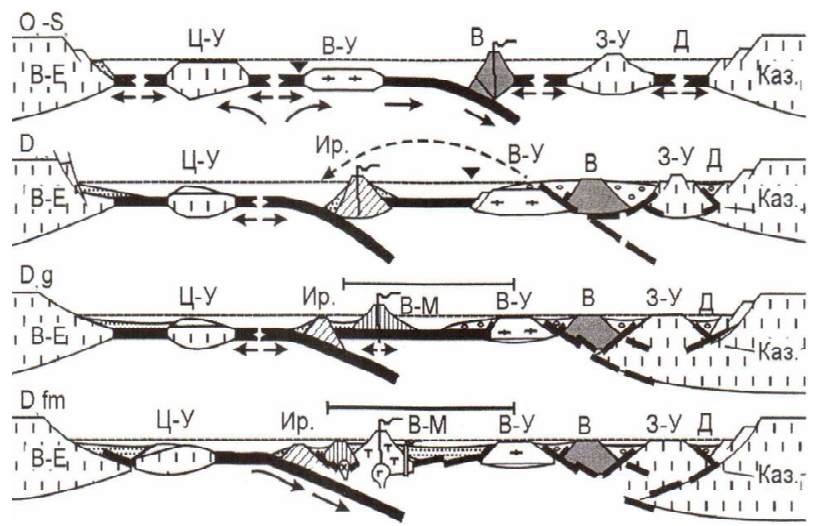

Figure 6. Shem of the geodynamic evolution of the Southern Urals in the Paleozoic. (by Yazev \& Bochkarev, in [7]: O-S - Ordovician, Silurian; D-Devonian. B-E-East Ural continent, Ka3 - Kazakhstan continent, Ц-У - Central Ural micro continent, В-У-East Ural, 3-У-West Ural, Ирirendykskaya island structure, B-M-East-Magnitogorsk island structure, B-Eastern zone, D—Denisovskaya zone.

erties, including the nature of acoustic emission.

It was established, that each of the samples has a special acoustic emission properties. Comparison with the published data allows to explain identified differences and to associate them with specific textural and structural characteristics of the studied samples and with the nature of the stress they experienced during the tectonic reconstruction of the Ural geological structures.

Acoustic emission (AE) is associated with the process of radiation of elastic waves by the material caused by local dynamic reorganization of its structure, as well as with destruction of the relations at the atomic and molecular level, with the power, thermal, electromagnetic, and other effects $[23,24]$. The practical application of this method is now used to study the memory effects in the rocks [25-27] and in the decision of methodological problems in the study of the parameters of acoustic emission in minerals and rocks which are different in composition and structure $[28,29]$.

Previously for Hawaiian basalts it was established [30], that the types of $\mathrm{AE}$ radiation determined by various factors: the composition of the phenocrysts and their size; the structure and constitution of the groundmass; the structure of the rocks and filling of the pores. In the studied serpentine samples the maximum energy of high-frequency radiation $(1-5 \mathrm{MHz})$ does not change in all groups and amounts to $37 \mathrm{~dB}$; midrange radiation $(0.1-1$ $\mathrm{MHz}$ ) amounts on the average of $53 \mathrm{~dB}$ and low-frequency radiations $(<0.1 \mathrm{MHz})$ varies from 42 to $62 \mathrm{~dB}$ (average - $45 \mathrm{~dB}$ ). It should be noted that the samples with greater strength ( 8 and 9 ) have 2 peaks of midrange radiation, which reflect the formation of a main destructtion surface, in contrast to other samples, in which the destruction occurs at the local levels.
The multiple types of AE activity (dependence of the number of pulses from the stress) were determined for the investigated samples of serpentinites. All curves have three characteristic segments: pulselessness of $\mathrm{AE}$, jump radiation of the $\mathrm{AE}$ and homogeneous radiation of the AE. Large number of cracks, microgranular structure, orroded contacts of mineral grains create conditions for continuous low-frequency radiation and extended lowfrequency energy range (Figure 7). As a result, the various types of emission curves were established for the sepentinites of the different genetic group.

If we turn to the first selected group of serpentinite (mantle genetic group), it is seen that the performance of medium and low-frequency radiation for all samples is almost the same both by the number of pulses and their maximum energy (Figure 7).

However, it was divided some different types of emission curves from different samples.

The first type of curve has the samples 8 from the first group. This sample is characterized by the non-oriented structure and relatively large pseudomorphs of olivine. The curve is characterized by approximately the same number of pulses in the frequency range from 500 to 3 $\mathrm{MHz}$ (Figure 7(a)). The total sum of such pulses with a maximum energy reaches to 4000 . Relatively coarsegrained structure of this sample is characterized regardless of the frequency by a large number of peak events (the release-absence) during the all time of the experiment until the complete destruction of the rock occurs. The overall high-frequency radiation in this sample is lower than in the sample 10, which has an oriented structure.

The second type of curve we can see in sample 10, when the AE radiation at the first stages of loading is absent and then there is a sharp burst in activity occurs (Figure 7(b)). In the future the overall level of the acoustic activity remains approximately constant, and on such background there are observed the presence of splashes of activity in the frequency range from $500 \mathrm{KHz}$ to 1 $\mathrm{MHz}$. The total amount of impulses of the same frequency and energy is about 4100. In this case (in sample 10 ), under load about half of the value of strength (at uniaxial compression), number of events is insignificant and then it increases sharply. The number of the highfrequency impulses in this case more and it is probably due to the grater amount of crumbling fibers of serpenttine.

The third type of curves (Figure 7(c)) is characteristic for the samples 9 and 7 of the second genetic group with a predominance of noble serpentine. Here we mostly see impulses with frequency from $500 \mathrm{KHz}$ up to $1 \mathrm{MHz}$ with the energy of 43 and $60 \mathrm{~dB}$, but their number is small. The overall level of radiation is very low (minimum for the three groups). In this group of rocks acous- 


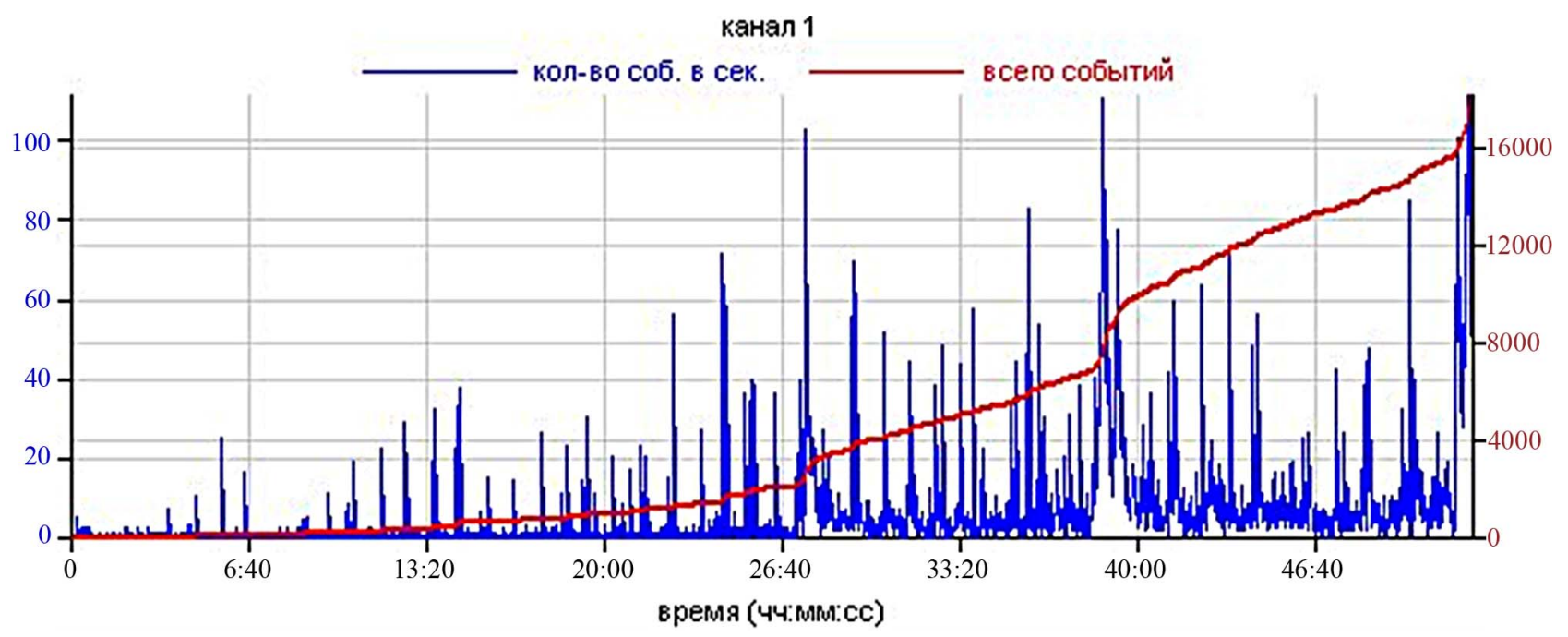

(a)

канал 1

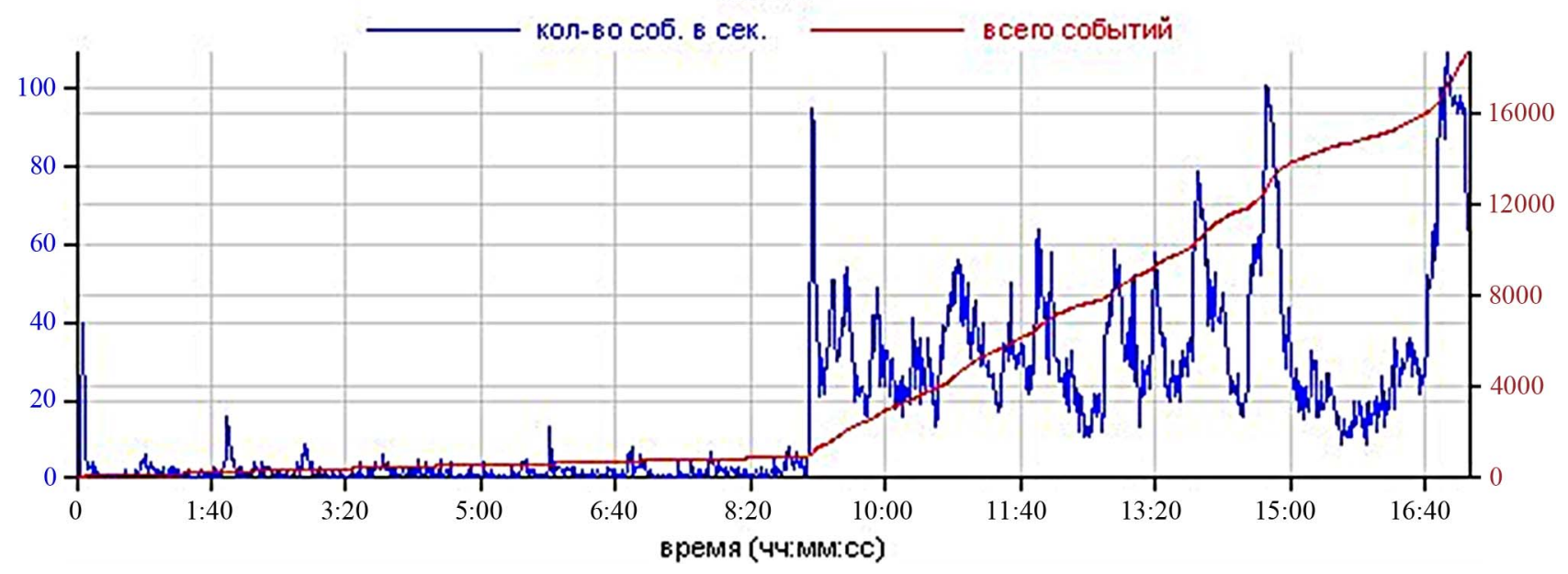

(b)

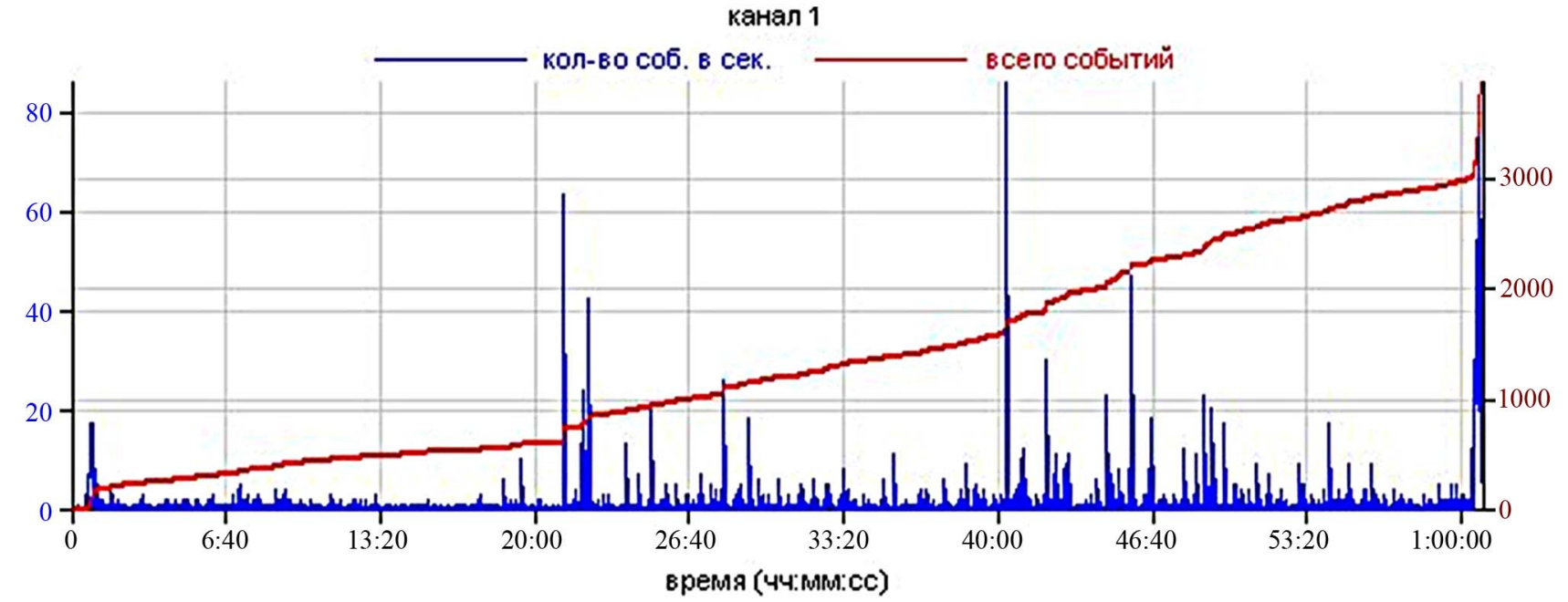

(c)

Figure 7. Types of AE activity curves under the equally loading of the serpentines: (a) sample 8; (b) sample 10; (c) sample 9. Blue curves show the number of events per second; red curves show the total number of pulses above the threshold of discrimination. 
tic emission radiation is approximately 2 to 3 times lower than in the rocks of the first group. A strong and sharp very short-term increase in activity occurs on this low background. It can be assumed that at this moment the destruction of serpentine threads takes place. Here we can see a clear dependence of the curve type on the evenly grained microcrystalline structure of serpentinite. on this low background of the acoustic activity (regardless of the strength of the rock) rare peak number of events take place in the high-frequency range and we can corresponded this events with the presence and destructtion of larger grains of carbonates. This situation is similar to the one previously observed by us during the study of Hawaiian basalts. These rockes have microcrystalline structure and $15 \%-30 \%$ content of irregularly distributed phenocrysts of olivine. The extended energy range of the radiation at low frequencies is observed also.

In the samples of the third genetic group were conducted tests only for the samples with non-oriented structure. Acoustic emission activity possesses features of all the previous types. The highest parameters $\mathrm{AE}$ among all varieties, both by the energy of all ranges, and by the number of pulses, were possessed by the serpentines of the sample 4 (despite the average strength of the samples). This is probably due to the high iron content in the primary protolith, larger amount of ore inclusions and increased micro- and macro-cracking.

\section{Conclusions}

The following conclusions could be done through the results of studies.

1) The first results of the study of acoustic emission (AE) of serpentinites under a constant speed of the load were obtained and analyzed. It was established, that the samples of different genetic types have a different shape of $\mathrm{AE}$ curves and it is caused by differences in their textural and structural characteristics, which were formed in the magmatic, metasomatic and exogenous stages of their formation. For this type of the rock such studies were done at the first time.

2) Complex mineralogical and petrophysical study of serpentinites, developed after ultramafic rocks at the area of the Main Uralian Fault (GUR-Paleozoic subduction zone) indicate that the studied rocks are formed in different geological conditions. Three genetic groups of serpentinites, which differ in their mineral and chemical composition, the structural-textural features and petrophysical properties, including the speed of elastic waves and acoustic emission were divided. Serpentinites of the first group have an ultramaphic protholites and formed at the mantle depth. Serpentinites of the second group has a carbonate protholites and formed near the surface of the Earth. Serpentine of the third group has a maphic protho- lite and formed at the lithosphere.

3) Variations of the main physical parameters of the serpentinites, which were obtained on the basis of the research, including their mechanical properties and values of the velocities of the elastic waves, shows that it is't possible to correctly compare the values of the physical properties of minerals obtained in the singlecrystal experiments with measurements of natural objects, which were made for huge massif.

\section{Acknowledgements}

The authors thank all the staff of the Geological Faculty of the Lomonosov Moscow State University, who helped us in our researches: Elena B. Cherepetskaya, Igor A. Bryzgalov, Evgeniya B. Bushueva, Natalia N. Korotaeva, Lubov V. Melchakova, Aleksey A. Burmistrov, Vladimir M. Ladygin, Dmitry A. Ksenofontov.

\section{REFERENCES}

[1] S. Speziale, H. Marquardt, M. Koch-Müller, K. Marquardt, G. Capitani, S. Jahn and M. Wilke, "High-Pressure Brillouin and Raman Spectroscopy of a Natural Antigorite Single-Crystal," Abstracts of the European Mineralogical Conference, 2-6 September 2012, Frankfurt.

[2] L. Bezacier, B. Reynard, J. D. Bass, C. Sanchez-Valle and B. Van de Moortèle, "Elasticity of Antigorite, Seismic Detection of Serpentinites, and Anisotropy in Subduction Zones," Earth and Planetary Science Letters, Vol. 289, No. 1-2, 2010, pp. 198-208.

[3] A. D. Rosa, C. Sanchez-Valle, J. Wang and A. Saikia, "Single-Crystal Elasticity of Superhydrous Phase B, $\mathrm{Mg}_{10} \mathrm{Si}_{3} \mathrm{O}_{18} \mathrm{H}_{4}$, by Brillouin Scattering Spectroscopy, Proceeding of the IMA conference, DE41: Mineralogy of the Deep Earth, 2010, p. 145

[4] M. Murakami, "Sound Velocities of Earth's Deep Materials," Proceeding of the IMA conference, DE41-Mineralogy of the Deep Earth, 2010, p. 150

[5] M. Gemmi, M. Merlini, J. Fischer, S. Poli, E. Mugnaioli and U. Kolb, "A New Hydrated High Pressure Phase in the MASH System," Proceeding of the IMA conference, DE41: Mineralogy of the Deep Earth, 2010, p. 149

[6] G. A. Petrov and V. N. Puchkov, "Main Uralian Fault in the Northern Urals," Geotectonics, Vol. 1, 1994, pp. 25-37.

[7] T. O. Fedorov and L. M. Rastsvetaev, "Late-Hertzinium Structure of the Axial Zone of the Urals and Its Geodynamic Interpretation," MSU Publications, Moscow, 1998.

[8] A. S. Varlakov, "Rock-Forming Serpentine from the Ultramafic Rocks," Notes of the Russian Mineralogical society, No. 6, 1990, pp. 60-70.

[9] A. S. Varlakov, "Serpentine and Serpentinite from the Bakal and Satka Deposits," Notes of the Russian Mineralogical Society, No. 4, 2000, pp. 89-94.

[10] E. B. Cherepetskaya, V. N. In'kov and V. L. Shkuratnik, "Laser Ultrasonic Spectroscopy for Geological Tasting," 
Forum Acusticum, Budapest, 29 August-2 September 2005, pp. 2789-2794.

[11] C. S. Herlbut and C. Klein, "Manual of Mineralogy (after J. D. Dana)," 19th Edition, John Wiley \& Sons, New York, 1982.

[12] G. N. Vertushkov and V. N. Avdonin, "Tables for the Diagnostic of Minerals after Physical and Chemical Properties," Nedra, Moscow, 1992.

[13] H. Strunz and E. H. Nickel, "Strunz Mineralogical Tables: Chemical-Structural Mineral Classification System," Schweizerbart, Leipzig, 2001.

[14] N. B. Dortman, "Physical Properties of the Rocks and Mineral Resources. Handbook of the Geophysicist," Nedra, Moscow, 1984.

[15] B. M. Urazaev, "Physical Properties of the Rocks and Geophysical Fields," Nauka, Alma-Ata, 1971.

[16] N. N. Zinchouk, A. T. Bondarenko and M. N. Garat, "Petrophysics of Kimberlites and Their Country Rocks," Nedra, Moscow, 2002.

[17] J. B. Dawson and W. E. Stephens, "Statistical Analysis of Garnet from Kimberlites and Associated Xenoliths," The Journal of Geology, Vol. 83, No. 5, 1975, pp. 589-607. doi:10.1086/628143

[18] W. E. Stephens and J. B. Dawson, "Statistical Comparison between Pyroxenes from Kimberlites and Their Associated Xenoliths," The Journal of Geology, Vol. 85, No. 4, 1977, pp. 433-449. doi:10.1086/628317

[19] R. H. Mitchell, "Kimberlite, Orangite and Related Rocks," USA Plenum Press, New York, 1995.

[20] V. N. Puchkov, "Tectonics of the Urals. Modern Ideas," Geotectonics, Vol. 4, 1997, pp. 42-61.

[21] V. N. Puchkov, "Paleogeodynamics of the South and Middle Urals," Guillem Ed, Ufa, 2000.

[22] O. Navon, "Diamond Formation in the Earth's Mantle," Proceedings of the 7th International Kimberlite Con- ference, Cape Town, 13-17 April 1998, pp. 584-604.

[23] H. R. Hardly, "Application of Acoustic Emission Techniques to Rock Mechanics Research," Acoustic Emission, American Society for Testing and materials, 1972, pp. 41-83.

[24] A. V. Lavrov, V. L. Shkuratnik and Yu. L. Filimonov, "Acustic Emission Effect of the Memory in the Rocks," MGGU Publications, Moscow, 2004.

[25] L. L. Panasyan and M. A. Petrovsky, "About the Use of Kaiser Effect for the Estimation of the Stress in the Rocks," Engineering Geology, Vol. 2, 1984, pp. 114-119.

[26] G. A. Golodkovskaya, L. L. Panasiyan, M. A. Petrovsky and S. A. Kolegov, "New Aspects of Rock of Stress Study," Materials of the 5th ICIA of Engineering Geology, Rotterdam, 1986, pp. 435-439.

[27] A. Lehtonen, J. W. Cosgroveb, J. A. Hudson and E. Johansson, "An Examination of in Situ Rock Stress Estimation Using the Kaiser Effect," Engineering Geology, Vol. 124, 2012, pp. 24-37. doi:10.1016/j.enggeo.2011.09.012

[28] L. L. Panasiyan, S. A. Kolegov and A. N. Morgunov, "Stress Memory Studies in Rocks by Means of Acoustic Emission," International Conference on Mechanics of Jointed and Foulted Rock, Vienna, 1990, pp. 435-439.

[29] L. L. Panasyan and K. A. Schwartz, "Experience of Evaluation of Structure-Sensitive Factor with Acoustic Emission," Materials of the Scientific Conference of the Session Russian Academic Science Council of the Acoustics, 2011, pp. 300-304.

[30] L. L. Panasiyan, V. M. Ladygin and V. B. Kurnosov, "Connection of the Acoustic Emission with the Structure in Basalts of the Hawaii Islands," Proceedings of the Science Acoustic Council of Russian Academy of Science and XXV Session of the Russian Acoustic society, Moscow, 2012, pp. 349-351. 